\title{
Synthesis of Carbon-Base Materials by Microwave Irradiation of Peat
}

\author{
Natalia Konstantinovna Kitaeva ${ }^{1}$ \& Ekaterina Aleksandrovna Bannova ${ }^{1}$ \\ ${ }^{1}$ Obninsk Centre for Science and Technology, Gorky str., 4, 249033 Obninsk, the Kaluga region, Russian \\ Federation \\ Correspondence: Natalia K. Kitaeva, Gorky str., 4, 249033 Obninsk, the Kaluga region, Russian Federation. Tel: \\ 7-930-751-1865. E-mail: kitaeva.natalia@gmail.com
}

Received: December 15, 2014

Accepted: December 20, 2014

Online Published: March 25, 2015

doi:10.5539/mas.v9n5p71

URL: http://dx.doi.org/10.5539/mas.v9n5p71

\begin{abstract}
The production of carbon adsorbents by carbonization of peat under the effect of microwave irradiation within the environment of own gases was studied. The optimization of conditions and parameters for carbonization of peat was conducted. By means of FTIP-spectroscopy, elemental analysis, thermographic analysis, nitrogen sorption-desorption and model indicators' occlusion it was found that in consequence of carbonization the content of loaded surface sites is reduced due to the destruction of functional organic compounds, dispersion is decreased, adsorption properties of carbon-base materials are increased.
\end{abstract}

Keywords: peat, carbonization, carbon-base material, adsorption, microwave irradiation

\section{Introduction}

At the present time for cleaning of both, water and gas environments, various methods are applied. However, the most interesting method is presented with adsorption that is being quite effective and in case of multistage organization of process can provide the cleaning up to any required level (Fellenberg, 1997; Koganovsky et. al., 1981; Keltsev, 1984).

In the majority of cases the best results of sorption cleaning of water environments is achieved with applying of synthetic adsorbents due to their high sorption properties and the possibility of re-use.

Among the natural adsorbents the leading position is taken by adsorbent (activated) carbons. They possesses high sorption properties and are being more eco-friendly in comparison with synthetic adsorbents, as they are easy-disposed and non-toxic, relatively cheap, quite available and can be exposed to biodegradation (Smirnov, 1982; Plachenov et. al., 1983; Kinle \& Bader, 1984).

The main raw material for production of activated carbons is timber of hard-wooded broad-leaved species, primarily - of birch (Muhin et. al, 2000; Plachenov et. al., 1983). Nowadays there is a vexed problem with raw materials for production of activated carbons that can be solved by extension of raw material base.

In recent years the methods of carbon-based materials production from cheap and available plant and natural organic raw materials are actively developed (Belyaev, 2000; Hu et al., 2010; Deng et al., 2010; Dolgih and Ovcharov, 2010; Alslaibi et al., 2013). In the production the following materials are used: peat (Novoselova \& Sirotkina, 2008), wood wastes (Miura et al., 2004; Eremina et al., 2011; Kuznetsov et al., 2002; Semenovich and Loskutov, 2004), nutshell орехов (Bogaev et al., 2013; Egorova et al., 2007), coffee beans (Franca et al., 2010; Hirata et al., 2002), fruit pits (Isahak et al., 2013), etc.

Traditionally for carbonization of carbon-bearing materials recuperative ovens are used. In the process of thermal treatment in such ovens there is thermal decomposition of organic substances contained in processing materials, as a result of which high-carbon highly porous product is appeared (Plachenov et al., 1983; Hu et al., 2010; Bogaev et al., 2013; Isahak et al., 2013; Belyaev, 2013). However, since natural materials mainly possess low heat conductivity, such a way of production of carbon adsorbents differs with number of significant disadvantages: long duration of process, high energy consumption and unevenness of heating that leads to spotty quality of getting product. In addition, the unevenness of heating leads to formation in material of significant temperature gradients resulting in higher danger of spontaneous firing.

In recent years within the frameworks of synthesis of organic and inorganic compounds and processing of wide range of materials the increasing attention of researches in all over the world is attracted with microwave 
technology due to its unique characteristics. The applying of microwave irradiation for carbonization of plant and natural raw materials allows realizing process in shorter time and upon condition of lower temperatures that is being more effective and profitable in the context of power economy (Miura et al., 2004; Danilov, 2006; Deng et al., 2010; Franca et al., 2010; Danilov et al., 2011; Alslaibi et al., 2013).

In this regard the research of microwave carbonization of natural raw materials as well as of production wastes for the purpose of getting of carbon adsorbents is being quite actual task.

\section{Literature Review}

Unlike to thermal radiation the microwave irradiation forms inside the processing material the steady electromagnetic field, due to which the conversion of microwave energy to thermal one takes place only in irradiated material. This leads to the absence of temperature gradient through-the-thickness of material and allows processing it in shorter time and upon condition of lower temperatures that is being more effective and profitable in the context of power economy. In addition, we get the product being homogeneous in its characteristics. Besides, the microwave technologies of synthesis and processing of materials pertain to ecologically clean technologies what is being another one advantage.

The main requirement to effective influence of microwave irradiation on material is that the material should be dielectric and characterized with definite complex of dielectric properties (Danilov et al., 2010; Guiotoku et al., 2011). One of such materials is peat.

Peat is being wide spread mineral product, its reserves are quite significant and only reserves of coal are larger. The relative availability and low price, variety of material composition, multifunctionality of properties and diversity of structural characteristics make peat rather prospective raw material, i.a. for production of carbon adsorbents.

In its structure peat is presented with capillary porous multicomponent composite consisting of inhomogeneous organic mass, moisture and mineral inclusions of various content. The basis of organic mass is made with humic acids, bitumens, fulvic acids and cellulose. Peat can be considered as binary system "dry component - liquid". At such approach the result of microwave irradiation of peat will depend on both - the polarity of its "dry" component and the type and distribution of moisture within.

The polarity of peat's "dry" component is being in accordance with the volume of oxygen-containing functional groups possessing significant dipole moment $(-\mathrm{OH},-\mathrm{COOH}$ and others): the bigger the volume - the higher the polarity. In addition, the polar functional groups promote retaining moisture due to donor-acceptor interactions, what also increases peat's susceptibility to microwave processing.

The water that presents in peat in form of moisture differs with very high dielectric capacity, due to which it absorbs a great part of microwave irradiation, heats up and starts extensively to vaporize. For the water inside the processing material is being in closed space, with its boiling there is extra pressure resulting in increase of its boiling temperature. As a result of influence of microwave irradiation the three gradients defining diffusion rate (temperature, pressure, concentration) are directed from internal layers of material to its surface, what promotes the acceleration of diffusion of vapor-air mixture in the same direction, due to which the fast and effective processing of material becomes possible.

The peat's organic components containing polar groups heat up absorbing microwave irradiation. The further influence of microwave irradiation on the material in the absence of or upon the condition of limited access of air leads in consequence of decay of organic compounds to carbonization of material. The exhaling water vapors and pyrogases create extra pressure resulting in mechanical destruction presented with appearance of micro cracks and formation of pore system in material.

Earlier the authors in their work (Bannova et al., 2013) have approved the principal possibility of carbonizing peat under the effect of microwave irradiation.

The aim of this work is the selection of optimal indicators and conditions for influence of microwave irradiation on peat, studying of their impact on physical-chemical and absorption characteristics of getting carbon material.

\section{Materials and Methods}

In the present work the following materials were used: the terrestrial peat of moss group with dispersion of 1-2 $\mathrm{mm}$., preliminary dried to humidity of $15-17 \%$, benzol (highly purified), hexane (highly purified), iodine (titration standard), sodium thiosulphate (purified), methylene blue (analytical reagent grade), metanil yellow (analytical reagent grade).

The carbonization of peat was held in stationary microwave unit with frequency of $2.45 \mathrm{GHz}$ by the procedure 
specified in the work (Bannova et al., 2013).

The microwave power was equal to $620 \mathrm{~W}$, the time of carbonization made up $60 \mathrm{~min}$., apart from experiments, during which the dependence of carbonized peat's properties on the power of microwave irradiation and the time of carbonization had been studied.

The efficiency of influence of microwave irradiation was evaluated in accordance with loss of peat's mass that was determined gravimetrically - as the ratio between the difference in masses of initial and post-processed peat and the mass of initial peat expressed in \%.

The fractionation of peat and identification of peat's fractional composition were held by sieving method.

The functional analysis was conducted by the means of FTIR-spectroscopy with help of Scimitar 1000 FTIR-spectrometer with photo-acoustic adaptor. The samples were preliminary dried in vacuum drying cabinet and pounded in agate mortar.

The content of nitrogen, carbon, hydrogen and oxygen in the samples was defined with EURO EA 3000 elemental analyzer.

The thermographic analysis was conducted with help of Paulic and Co Q-1500D derivatograph, the final temperature made up $800^{\circ} \mathrm{C}$, the temperature rise rate was $10^{\circ} \mathrm{C} \cdot \mathrm{min}^{-1}$ in inert atmosphere (helium).

The adsorption capacity on absorbing vapors of benzol and hexane was evaluated by exsiccatory method of balanced pore filling upon stationary conditions at room temperature.

The porometric characteristics of peat samples were evaluated by gas-chromatographic method of nitrogen sorption-desorption with help of ASAP 2020 automatized system (USA).

The adsorption of model indicators was studied in static mode by method of limited volume.

The concentration of iodine in the solution was defined by titrimetric method.

The concentration of methylene blue and metanil yellow was evaluated spectrophotometrically by means of КФК-3-01 spectrophotometer with samples being in quartz cells with the thickness of absorbing layer of $1.0 \mathrm{~cm}$ and wave-length of 660-670 and 430-450 nm correspondingly.

\section{Results and Discussion}

\subsection{The Generality of the Process of Microwave Carbonization of Peat}

For the purpose of optimization of the process of carbonization we have studied the influence of power of microwave irradiation (Figure 1) and processing time (Figure 2) on carbonization peat.

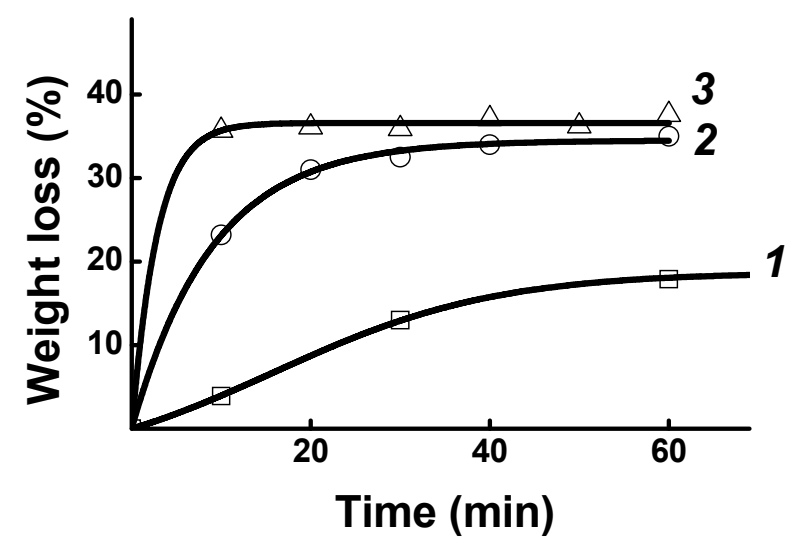

Figure 1. Kinetics of peat's mass loss upon conditions of different power of microwave irradiation. The power of microwave irradiation, $\mathrm{W}: 1-90 ; 2-380 ; 3-700$ 


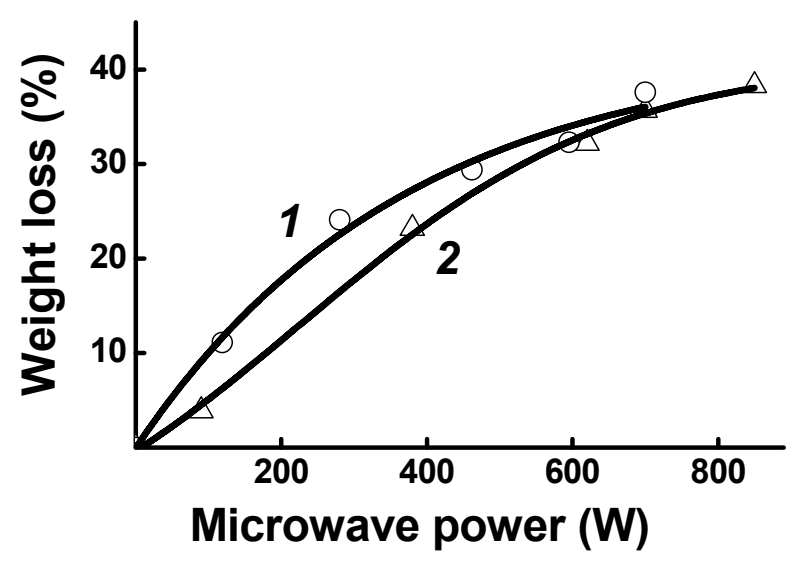

Figure 2. The dependence of peat's mass loss on power of microwave irradiation. Carbonization time, min: $1-$ $10 ; 2-60$

The studying of kinetics of microwave carbonization of peat (Figure 1) has shown that with increase of power of microwave irradiation the peat's mass loss also increases and reaches the maximum value of $60-62 \%$ at microwave power of $700 \mathrm{~W}$.

According to the data of Figure 2 we can say that in equal time of carbonization the increase of microwave irradiation power leads to increase of peat's mass loss.

The mathematical treatment of kinetic curves of microwave carbonization presented in Figure 1 has shown that initial rate of carbonization grows linearly with increase of power of microwave irradiation in examined range of powers (Table 1).

Table 1. The influence of power of microwave irradiation on initial rate of peat's carbonization.

\begin{tabular}{cc}
\hline The power of microwave irradiation, $\mathrm{W}$ & Initial rate of carbonization, $\% \cdot \mathrm{min}^{-1}$ \\
\hline 90 & 0.4 \\
380 & 1.9 \\
620 & 3.1 \\
700 & 3.5 \\
850 & 4.3 \\
\hline
\end{tabular}

The influence of microwave carbonization on change of fractional composition of peat was also studied. It was found that in the process of carbonization the dispersion of peat reduces, and in carbonized peat the part of particles with a size of less than $1.0 \mathrm{~mm}$. is about 80 mass \% opposite to 60 mass \% in initial peat.

\subsection{Physical-Chemical and Absorption Properties of Carbonized Peat}

The change of functional composition of the sample in the process of carbonization was studied by method of FTIR-spectroscopy (Figure 3). 


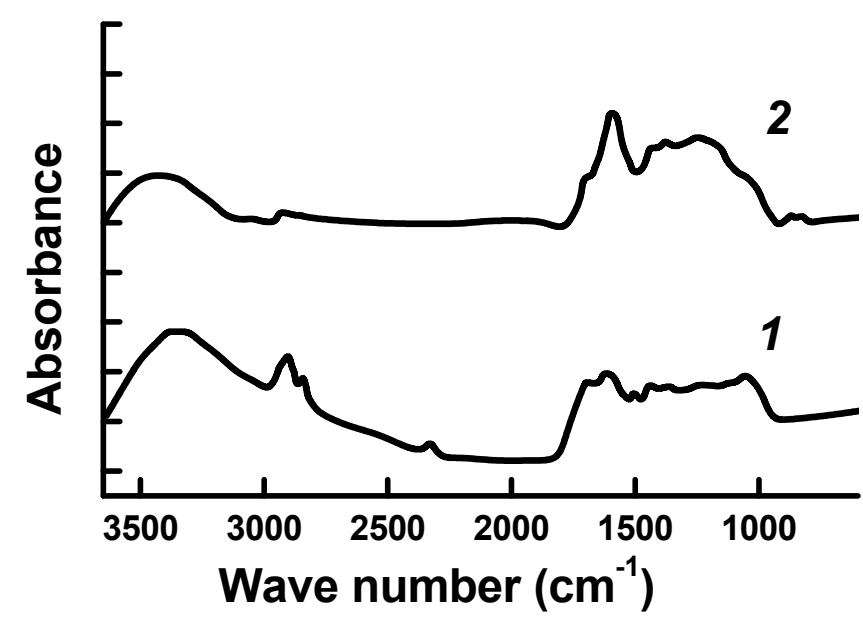

Figure 3. FTIR-spectra of initial (1) and carbonized (2) peat

From the presented in Figure 3 FTIR-spectra we can see that in carbonized sample in comparison with initial one there is a decrease of absorption bands related to valence and deformational vibrations of $\mathrm{O}-\mathrm{H}$ and $\mathrm{C}-\mathrm{O}$ in hydroxyl groups (spirituous and phenolic) in the range of $1300-900 \mathrm{~cm}^{-1}$; the absorption bands related to vibrations of $\mathrm{C}=\mathrm{O}$ bonds of carbonyl and carboxyl groups - in the range of $1700 \mathrm{~cm}^{-1}$; and the absorption bands related to vibrations of C-O-C bonds in simple ethereal groups - about $1000-1250 \mathrm{~cm}^{-1}$. Also we can see the reduction of absorption of $\mathrm{C}-\mathrm{H}$-bonds in methyl and methylene fragments of aliphatic structures in the ranges of $2960-2850,1485-1430$ and $1380-1340 \mathrm{~cm}^{-1}$. In the spectrum of carbonized sample there is a distinct increase of intensity of absorption bands related to valence vibrations of $\mathrm{C}=\mathrm{C}-\mathrm{C}=\mathrm{C}$ in the nucleus of condensed structures $\left(1600 \mathrm{~cm}^{-1}\right)$ in opposite to valence $\left(3100-3000 \mathrm{~cm}^{-1}\right)$ and deformational $\left(690-875 \mathrm{~cm}^{-1}\right) \mathrm{C}-\mathrm{H}$-vibrations of aromatic fragments (Пентин и Вилков, 2006; Abdel-Nasser and El-Hendawy, 2006).

According to analysis of compared spectra we can say that when carbonizing there is reduction of content of functional groups (primarily, oxygen-containing) as a result of destruction of organic component, as well as aromatization of structures, what is proven with increase of $\mathrm{C} / \mathrm{H}$ atomic ratio. The obtained data is finely conformed to the results of the work (Deng et al., 2010).

The results of elemental analysis confirm the supposition taken by method of FTIR- spectroscopy (Table 2). As we can see from the table as a result of carbonization there is removal of hydrogen and oxygen from the sample, in consequence of which the content of carbon and nitrogen increases.

Table 2. The results of elemental analysis of peat

\begin{tabular}{ccccc}
\hline & \multicolumn{4}{c}{ Content of element, mass \% } \\
& $\mathrm{N}$ & $\mathrm{C}$ & $\mathrm{H}$ & $\mathrm{O}$ \\
\hline initial & 0.48 & 50.0 & 5.44 & 39.9 \\
carbonized & 1.15 & 69.0 & 3.73 & 19.4 \\
\hline
\end{tabular}

The samples were also examined by method of complex thermal analysis conducted with help of derivatograph. The profiles of thermal decay of initial and carbonized samples are shown in Figure 4. 


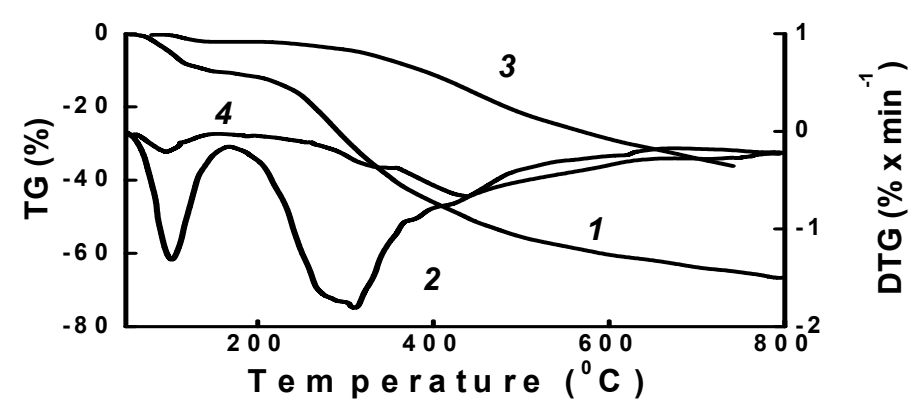

Figure 4. Thermogravimetric $(1,3)$ and differential thermogravimetric $(2,4)$ curves of initial $(1,2)$ and carbonized $(3,4)$ peat

Examining the thermogravimetric (TG) and differential thermogravimetric (DTG) curves of the samples we have emphasized two main temperature areas attended with gradual loss of sample mass: I - in low-temperature area up to $170{ }^{\circ} \mathrm{C}$ it is caused by the loss of physically-associated and adsorbed water; II - in high-temperature are up to $650{ }^{\circ} \mathrm{C}$ - as it is peculiar to thermal destruction of peat. The maximum rate of mass loss in initial and carbonized samples corresponds to 320 and $445{ }^{\circ} \mathrm{C}$ and for initial sample reaches $1.82 \% \cdot \mathrm{min}^{-1}$ and for carbonized sample $-0.7 \% \cdot \mathrm{min}^{-1}$. In case we increase temperature up to $650{ }^{\circ} \mathrm{C}$, the intensity of thermal decay processes reduces to $0.2 \% \cdot \mathrm{min}^{-1}$ and further steadily tends to its minimum at $800{ }^{\circ} \mathrm{C}$.

The results of processing of obtained thermograms are listed in Table 3. All the examined samples show general decrease in their masses at the second stage, moreover, for initial sample the interval of significant loss of mass is being a little wider than for carbonized one and linked to the intensive processes of thermal decay of macromolecules of the majority of organic compounds and also to transformation of C-C bonds into thermally more stable carbonic polyaromatic structures (Sun and Hong, 2011), what is also finely conformed to the results of FTIR-researches.

Table 3. The results of thermal analysis of peat

\begin{tabular}{cccccc}
\hline Stage & $\begin{array}{c}\text { Temperature } \\
\text { range, }{ }^{\circ} \mathrm{C}\end{array}$ & $\begin{array}{c}\text { Maximum } \\
\text { temperature, }{ }^{\circ} \mathrm{C}\end{array}$ & $\begin{array}{c}\text { Loss of mass by } \\
\text { stages, } \%\end{array}$ & Ash at $800{ }^{\circ} \mathrm{C}, \%$ \\
\hline \multirow{2}{*}{ initial } & I & $25-170$ & 90 & 10,3 & 33,1 \\
& II & $170-600$ & 320 & 50,0 & \\
carbonized & I & $27-150$ & 80 & 1,8 & 62,2 \\
& II & $195-650$ & 445 & 29,1 & \\
\hline
\end{tabular}

The most important property of carbon-based materials is their adsorption capacity that is linked to change of physical and chemical and porous structure of material within the process of carbonization.

When carbonizing, due to high temperature (up to $650{ }^{\circ} \mathrm{C}$ ) and release of volatile organic components as a result of complex of thermo-chemical reactions, in the sample there are new pores appeared that leads to expansion of specific surface. For evaluation of change of sample's porous structure within the process of carbonization we have measured the adsorption properties of initial and carbonized samples on absorption of vapors of benzol and hexane. The analysis of the results has shown that in the process of carbonization the porousness is developed and the adsorption properties of carbon-based materials concerning the vapors of hydrophobic molecules are increased. It was found that the carbonized sample can accumulate up to $0.6 \mathrm{~g}$ of benzol and $0.45 \mathrm{~g}$ of hexane for $1 \mathrm{~g}$ of adsorbent in comparison with the initial sample ( $0.08 \mathrm{~g}$ and $0.11 \mathrm{~g}$ correspondingly). Apparently, the porous structure of carbonized sample has size and form of pores close to adsorbing molecules.

The examination of porous structure of carbonized sample by method of nitrogen sorption-desorption has shown that within the process of carbonization there are micropores and pores of transitional size and slot-like form appear, which is being mostly common with carbon adsorbents (Lua et al., 2004; Almazan-Almazan et al., 2007). In addition, we can observe the tendency for increase of specific surface in case of increase of microwave irradiation power and carbonization time. 
The adsorption of model indicators (iodine, MB and MY) was measured upon static conditions. In Figure 5 there is an influence of microwave power on adsorption capacity of carbonized peat regarding iodine, MB and MY.

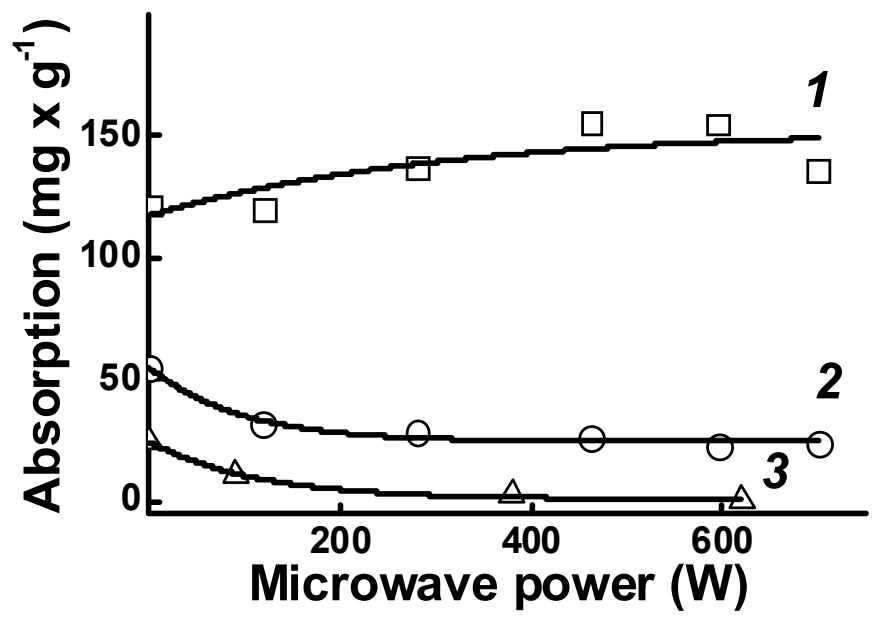

Figure 5. Dependence of iodine adsorption (1), MB (2) and MY (3) on microwave power

As we can see from Figure 5, when carbonizing the adsorption of iodine gradually increases, while, regarding MB and MY, it reduces with increase of microwave irradiation power. The dependence of adsorption capacity of carbonized samples regarding iodine, MB and MY, on carbonization time has similar character. Such a difference in adsorption capacity of carbonated coal regarding iodine, MB and MY, is linked to the fact that adsorption depends on both - the total specific surface of material (with account for the surface of pores) and the nature of its surface, i.a. on hydrophilic-lipophilic balance, content of surface functional groups that can form compounds and complexes with participation of adsorbate molecules. The difference in adsorption of iodine, MB and MY, on solid surface is that MB is mainly adsorbed on acid and MY - on main surface sites. At that iodine is adsorbed on both - the uncharged (hydrophobic) sites of surface and partially on the positively charged sites due to the fact that in water solutions the molecular iodine is being in equilibrium with ionic forms (iodide and iodate, which are formed with deterioration of hypoiodide acid). On the basis of obtained data we can conclude that within the process of carbonization the content of charged surface sites is reduced due to destruction of functional organic compounds.

We have taken the isotherms of iodine adsorption in initial and carbonized samples of peat (Figure 6).

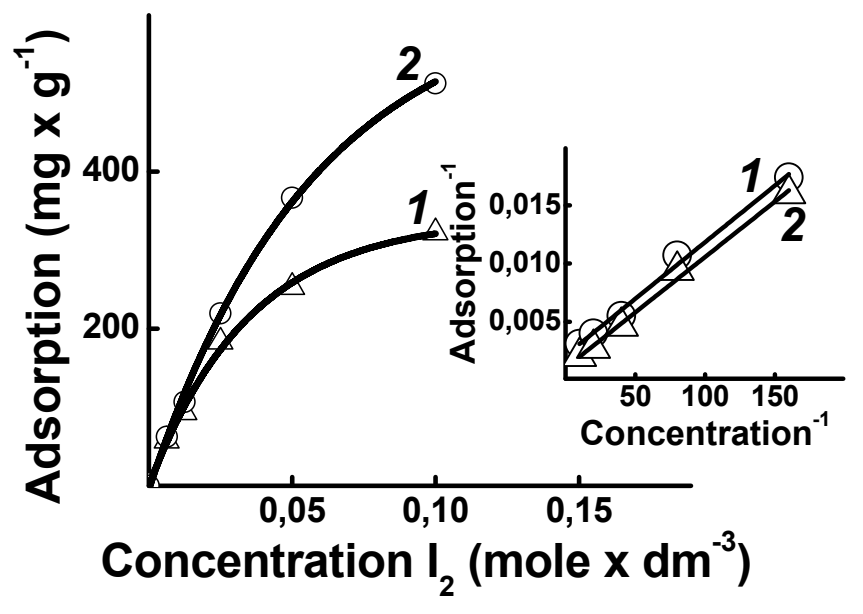

Figure 6. Adsorption of iodine in initial (1) and carbonized (2) peat

The analysis of adsorption isotherms has shown they have usual convex form and within studied limits can be described with Langmuir equation as well as the present works (Franca et al., 2010). 


\section{Conclusions}

In the course of conducted research we have studied the common factors of the process of peat carbonization within the environment of own gases and selected the optimal parameters of the process.

The examination of physical and chemical characteristics of getting material has confirmed that in the process of influence of microwave irradiation there is destruction of organic compounds of peat leading to decrease of content of oxygen-containing groups and aromatization structures and also to increase of carbon, expansion of specific surface and reduction of dispersion.

It was found that adsorption activity of carbonized material regarding iodine is significantly increased and regarding methylene blue and metanil yellow - reduced.

In such a way, the results of performed studies prove the possibility of using microwave irradiation for production of carbonic material based on peat.

\section{Acknowledgement}

The work was executed with financial support from Ministry of Education and Science of the Russian Federation. The unique identifier of applied scientific researches (project): RFMEFI57614X0008.

\section{References}

Abdel-Nasser, A., \& El-Hendawy. (2006). Variation in the FTIR spectra of biomass under impregnation, carbonization and oxidation conditions. Journal of Analytical and Applied Pyrolysis, 2(75), 159-166.

Almazan-Almazan, M. C., Perez-Mendoza, M., Domingo-Garcia, M., Fernandez-Morales, I., del Rey-Buengo, F., Carcia-Rodriguez, A., \& Lopez-Garzon, F. J. (2007). The role of the porosity and oxygen groups on the adsorption of n-alkanes, benzene, trichloroethylene and 1,2-dichloroethane on active carbons at zero surface coverage. Carbon, 9(45), 1777-1785. http://dx.doi.org/10.1016/j.carbon.2007.05.003

Alslaibi, T. M., Abustan, I., Ahmad, M. A., \& Foul, A. A. (2013). A Review: Production of Activated Carbon From Agricultural Byproducts Via Conventional and Microwave Heating. Journal of Chemical Technology and Biotechonology, 7(88), 1183-1190. http://dx.doi.org/10.1002/jctb.4028

Bannova, E. A., Kitaeva, N. K., Merkov, S. M., Muchkina, M. V., Zaloznaya, E. P., \& Martynov, P. N. (2013). Modified peat-based hydrophobic sorbent production process study [Izuchenie sposoba polucheniya gidrofobnogo sorbenta na osnove modifitsirovannogo torfa], Sorbtsionnye i hromatograficheskie processy, l(13), 60-68.

Belyaev, E. Y. (2000). Production and application of wood active carbons in for environmental purposes [Poluchenie i primenenie drevesnyh aktivirovannyh ugley $\mathrm{v}$ ekologicheskih tselyah]. Himiya rastitelnogo syrya, (2), 5-15.

Bogaev, A. V., Lebedev, I. A., Karchevskij, D. F., Berestennikov, D. A., \& Vtorushina, O. O. (2013). Active carbons production of pine nut shell [Poluchenie aktivnyh ugley iz skorlupy kedrovogo oreha]. Polzunovsky Vestnik, (1), 282-284.

Danilov, O. S. (2006). Alternative ways for active carbon production [Alternativnye puti polucheniya aktivnogo uglya], Gorny informatsionno-analiticheskiy byulletet, (2), 165-169.

Danilov, O. S., Miheev, V. A., \& Moskalenko, T. V. (2010). Microwave treatment of solid fossil fuels [Mikrovolnovaya obrabotka tverdyh goryuchih iskopaemyh], Gorny informatsionno-analiticheskiy byulletet, (3), 203-208.

Danilov, O. S., Miheev, V. A., \& Moskalenko, T. V. (2011). Studies of the effect of electromagnetic microwave radiation on solid fossil fuels [Issledovanie vliyaniya elektromagnitnogo mikrovolnovogo izlucheniya na tverdye goryuchie iskopaemye], Izvestiya Samarskogo nauchnogo centra Rossiyskoy akademii nauk, 1-5(13), 1264-1267.

Deng, H., Li, G., Yanga, H., Tanga, J., \& Tanga, J. (2010). Preparation of activated carbons from cotton stalk by microwave assisted $\mathrm{KOH}$ and $\mathrm{K}_{2} \mathrm{CO}_{3}$ activation. Chemical Engineering Journal, 3(163), 373-381. http://dx.doi.org/10.1016/j.cej.2010.08.019

Dolgih, O. G., \& Ovcharov, S. N. (2010), Plant waste-based carbonic adsorbents use for oil-contaminated waste water treatment [Ispolzovanie uglerodnyh adsorbentov na osnove rastitelnyh othodov dlya ochistki neftezagryaznennyh stochnyh vod], Vestnik Severo-Kavkazskogo gosudarstvennogo tehnicheskogo universiteta, 1(22), 1-7. 
Egorova, E. Y., Mitrofanov, R. Y., \& Lebedeva, A. A. (2007). Sorbent production of pine nut shell using cold-processing technique [Poluchenie sorbenta iz skorlupy kedrovogo oreha metodom nizkotemperaturnoy obrabotki]. Polzunovsky Vestnik, 3, 35-39.

Eremina, A. O., Golovina, V. V., Chesnokov, N. V., \& Kuznecov, B. N. (2011). "Carbonic adsorbent of hydrolized lignin for sewage water treatment" ["Uglerodnye adsorbenty iz gidroliznogo lignina dlya ochistki stochnyh vod"], Zhurnal Sibirskogo federalnogo universiteta. Series: Himiya, 1(4), 100-107.

Fellenberg, G. (1997). Environment Pollution: Introduction to Ecological Chemistry [Zagryaznenie prirodnoy sredy: Vvedenie v ekologicheskuyu himiyu], Moscow: Mir.

Franca, A. F., Oliveira, L. S., Nunes, A. A., \& Alves, C. C. O. (2010). Microwave assisted thermal treatment of defective coffee beans press cake for the production of adsorbents. Bioresource Technology, 3(101), 1068-1074. http://dx.doi.org/10.1016/j.biortech.2009.08.102

Guiotoku, M., Claudia, M. B. F. Maia, Rambo, C. R., \& Hotza, D. (2011). Synthesis of Carbon-Based Materials by Microwave Hydrothermal Processing. Microwave Heating, 291-308.

Hirata, M., Kawasaki, N., Nakamura, T., Matsumoto, K., Kabayama, M., Tamura, T., \& Tanada, S. (2002). Adsorption of Dyes onto Carbonaceous Materials Produced from Coffee Grounds by Microwave Treatment. Journal of Colloid and Interface Science, 1(254), 17-22. http://dx.doi.org/10.1006/jcis.2002.8570

Hu, B., Wang, K., Wu, L., Yu, S. H., Antonietti, M., \& Titirici, M. M. (2010). Engineering Carbon Materials from the Hydrothermal Carbonization Process of Biomass. Advanced Materials. Special Issue: Carbon Materials, 7(22), 813-828. http://dx.doi.org/10.1002/adma.200902812

Isahak, Wan, N. R. W., Hisham, Mohamed, W. M., Yarmo, \& Mohd, A. (2013). Highly Porous Carbon Materials from Biomass by Chemical and Carbonization Method: A Comparison Study. Hindawi Publishing Corporation. Journal of Chemistry, Article ID 6203466 p.

Keltsev, N. V. (1984). Absorption technique basics [Osnovy adsorbtsionnoy tehniki]. Moscow: Himiya.

Kinle, H., \& Bader, E. (1984). Active carbons and their industrial application. [Aktivnye ugli i ih promyshlennoe primenenie], Leningrad: Himiya.

Koganovsky, A. M., Levchenko, T. M., Roda, I. G., \& Marutovsky, R. M. (1981). Absorption wastewater technology [Adsorbtsionnaya tehnologiya ochistki stochnyh vod], Kiev: Tehnika.

Kuznecov, B. N., Golovin, Y. G., Golovina, V. V., Eremina, A. O., \& Levdansky, V. A. (2002). Preparation of carbonic adsorbents of extraction processing products of Siberian larch bark. [Poluchenie uglerodnyh adsorbentov iz produktov ekstraktsionnoy pererabotki kory listvennitsy sibirskoy]. Himiya rastitelnogo syrya, (2), 57-61.

Lua, A.Ch., Yang, T., \& Guo, J. (2004). Effects of pyrolysis conditions on the properties of activated carbons prepared from pistachio-nut shells. Journal of Analytical and Applied Pyrolysis, 2(72), 279-287. http://dx.doi.org/10.1016/j.jaap.2004.08.001

Miura, M., Kagaa, H., Sakurai, A., Kakuchi, T., \& Takahashi, K. (2004). Rapid pyrolysis of wood block by microwave heating. Journal of Analytical and Applied Pyrolysis, (71), 187-199. http://dx.doi.org/10.1016/S0165-2370(03)00087-1

Muhin, V. M., Tarasov, A. V., \& Klushin, V. N. (2000). Active carbons of Russia [Aktivnye ugli Rossii], Moscow: Metallurgiya.

Novoselova, L. Y., \& Sirotkina, E. E. (2008). Peat-based sorbents for polluted environment clearing. [Sorbenty na osnove torfa dlya ochistki zagryaznennyh sred]. Himiya tverdogo tela, (4), 64-77.

Pentin, Y. A., \& Vilkov, L. V. (2006). Physical investigative techniques in chemistry [Fizicheskie metody issledovaniya v himii], Moscow: Mir.

Plachenov, T. G., Galkin, V. A., \& Glushankov, S. L. (1983). Carbonic adsorbent and their industry application. [Uglerodnye adsorbenty $\mathrm{i}$ ih primenenie $\mathrm{v}$ promyshlennosti], Moscow: Nauka.

Semenovich, A. V., \& Loskutov, S. R. (2004). Cationic dyes adsorption with modified coniferous wood species bark [Adsorbciya kationnyh krasiteley modifitsirovannoy koroy hvoynyh drevesnyh porod], Himiya rastitelnogo syrya, 3, 121-125.

Smirnov, A. D. (1982). Sorbate Water Treatment [Sorbtsionnaya ochistka vody], Leningrad: Khimiya.

Sun, M., \& Hong, L. (2011). Impacts of the pendant functional groups of cellulose precursor on the generation of 
pore structures of activated carbons. Carbon, 7(49), 2173-2180.

\section{Copyrights}

Copyright for this article is retained by the author(s), with first publication rights granted to the journal.

This is an open-access article distributed under the terms and conditions of the Creative Commons Attribution license (http://creativecommons.org/licenses/by/3.0/). 